Men who have sex with men in Eastern Europe: a time to act

Lazarus, Jeff; Matic, Srdan

Published in:

Journal of LGBT Health Research

Publication date:

2009

Document version

Publisher's PDF, also known as Version of record

Citation for published version (APA):

Lazarus, J., \& Matic, S. (2009). Men who have sex with men in Eastern Europe: a time to act. Journal of LGBT Health Research, 5, 1-3. 
This article was downloaded by: [Lazarus, Jeffrey $V$.

On: 3 December 2009

Access details: Access Details: [subscription number 917418207]

Publisher Routledge

Informa Ltd Registered in England and Wales Registered Number: 1072954 Registered office: Mortimer House, 3741 Mortimer Street, London W1T 3JH, UK

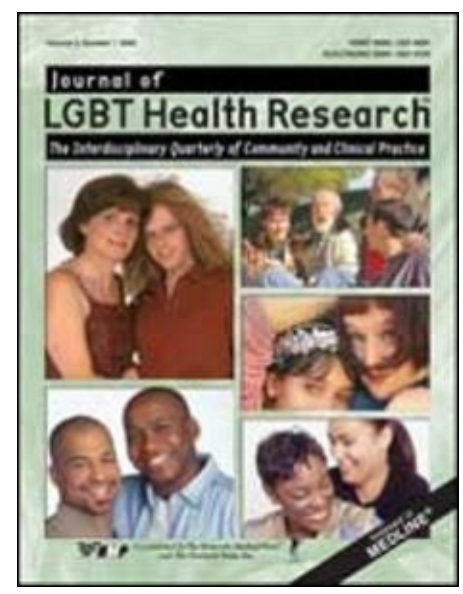

\section{Journal of LGBT Health Research}

Publication details, including instructions for authors and subscription information:

http://www.informaworld.com/smpp/title content=t792306928

\section{Men Who Have Sex with Men in Eastern Europe: A Time to Act}

Jeffrey V. Lazarus a; Srdan Matic ${ }^{a}$

${ }^{a}$ World Health Organization Regional Office for Europe,

Online publication date: 03 December 2009

To cite this Article Lazarus, Jeffrey V. and Matic, Srdan(2009) 'Men Who Have Sex with Men in Eastern Europe: A Time to Act', Journal of LGBT Health Research, 5: 1, 1 - 3

To link to this Article: DOI: $10.1080 / 15574090903327935$

URL: http://dx.doi.org/10.1080/15574090903327935

\section{PLEASE SCROLL DOWN FOR ARTICLE}

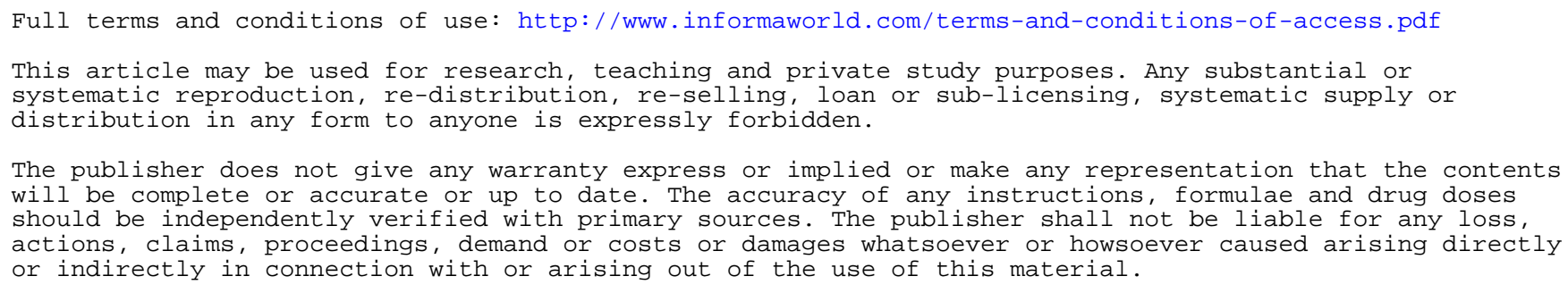

The publisher does not give any warranty express or implied or make any representation that the contents will be complete or accurate or up to date. The accuracy of any instructions, formulae and drug doses should be independently verified with primary sources. The publisher shall not be liable for any loss, actions, claims, proceedings, demand or costs or damages whatsoever or howsoever caused arising directly or indirectly in connection with or arising out of the use of this material. 


\title{
Men Who Have Sex with Men in Eastern Europe: A Time to Act
}

\author{
Jeffrey V. Lazarus \\ Srdan Matic
}

Throughout the 53 countries of the World Health Organization (WHO) European Region, HIV transmission is concentrated in specific networks of people, including those who inject drugs, engage in male-male sex, or come from certain high-prevalence countries. Men who have sex with men (MSM) are notably at risk for HIV; while the overall adult HIV prevalence in the Region is estimated to be as high as $1.3 \%$, prevalence among MSM has been documented to be at least 5\% in countries such as Estonia, Latvia, the Russian Federation, Ukraine, and Uzbekistan (Bozicevic, Voncina, Zigrovic, Munz, \& Lazarus, in press).

Approximately 1.5 [1.1-1.9] million people in the region are already living with HIV. Their number is steadily increasing, with MSM being at particular risk (UNAIDS, 2009a; WHO Regional Office for Europe, 2009). It is further worth noting that some two-thirds of those estimated to be living with HIV are unaware of their status.

During the Second Eastern Europe and Central Asia AIDS Conference, held in Moscow in spring 2008, researchers and advocates at a jam- packed session on MSM and HIV in Eastern Europe drew attention to the lamentable state of HIV prevention, treatment, and care in most countries of the former Soviet Union, particularly for members of risk groups. The session set out to highlight the importance of surveys and monitoring of HIV prevalence and behavioral risk factors among MSM in the forecasting of the development of the HIV epidemic, and presenters underscored the fact that MSM were still invisible in most official surveillance reports, even those from countries with burgeoning HIV caseloads.

For instance, in their official reports to the United Nations on progress in responding to HIV/AIDS, even in eastern European countries where MSM are mentioned, they are often absent from the list of major risk groups and/or almost nonexistent in official statistics (UNAIDS 2009b).

In response to the concerns raised at the Moscow conference, WHO Europe sponsored two in-depth looks at MSM and HIV in the countries of Central and Eastern Europe-a May, 2008, consultation in Bled, Slovenia (WHO

Jeffrey V. Lazarus, PhD, MSc, and Srdan Matic, MD, were both affiliated with the World Health Organization Regional Office for Europe at the time of writing. Dr. Lazarus now works for the Global Fund.

Address correspondence to: Jeffrey V. Lazarus, PhD, MSc, The Global Fund to Fight AIDS, Tuberculosis and Malaria, Chemin de Blandonnet 8, CH-1214 Vernier, Geneva, Switzerland (E-mail: jeffLaz@pubhealth.ku.dk). 
Regional Office for Europe, 2008), and a subsequent literature review. For the review, national experts from 27 countries combed the literature in their native languages, uncovering reports of the deeply rooted stigmatization of MSM in almost every country, which indicates that stigmatization and discrimination are major barriers to MSM accessing proper care and treatment for sexually transmitted infections, including HIV. An article summarizing the review's main findings by country starts on page 33 .

\section{PROGRAMMING FOR MSM AND HIV}

During the past year, various nongovernmental organizations (NGOs), UN agencies, and the Global Fund to Fight AIDS, Tuberculosis and Malaria have taken decisive action to address MSM and HIV.

Led by the Foundation for AIDS Research (amfAR), and with the support of WHO, the MSM Initiative is mobilizing urgently needed HIV programming aimed specifically at MSM in Eastern Europe. One recent result of this effort has been a small-grants program to fund community-led research, advocacy, health promotion, and health services for MSM. The MSM Initiative issued a request for proposals in December 2008 and distributed it widely in both Russian and English, utilizing the networks of AIDS Action Europe, the AllUkrainian Network of People Living with HIV (PLWH), the Eastern Europe and Central Asia Union of PLWH Organizations, the Eastern European Harm Reduction Network, the European AIDS Treatment Group, International Lesbian and Gay Association-Europe (ILGAEurope), the International Treatment Preparedness Coalition-Russia, UNAIDS, the United Nations Development Programme (UNDP), and WHO Europe.

The Initiative received 80 funding applications from more than 26 countries. A peer review panel met in March, 2009, to evaluate and score applications, leading to the funding of 10 organizations from Azerbaijan, Belarus, Estonia, Kazakhstan, Russia, Serbia, Turkey, and Ukraine. The MSM Initiative is now planning to award a second round of grants in 2010. Meanwhile, it has been working with experts across Eastern Europe to support local MSM-led efforts, including monitoring, technical assistance, and regional networking to promote advocacy and the exchange of program experiences.

These modest grants, funded by amfAR and AIDS Fonds Netherlands, are intended to be catalytic and help meet the need for strong HIVrelated programming by and for MSM in the countries of Eastern Europe and Central Asia. By supporting and helping to sustain innovative HIV programs, the grant program not only provides urgently needed interventions, but it can also pilot models that can be subsequently adapted and scaled up locally. One effective way to expand such efforts is to make MSM and other relevant sexual minorities part of Global Fund country coordinating mechanisms and part of grant applications to the Global Fund. Starting with Round 10, the Global Fund is requiring that all applications address sexual minorities, as set out in its recently launched Sexual Orientation and Gender Identities Strategy.

Such international support is particularly critical in the face of new governmental restrictions on homosexuality. On June 16, 2009, for example, the Seimas, Lithuania's parliament, overwhelmingly adopted an amended Law on the Protection of Minors against the Detrimental Effect of Public Information (67 votes for, 3 against, and 4 abstentions). According to this law, "propaganda of homosexuality and bisexuality" has a detrimental effect on minors, and information on homosexuality and bisexuality would thus be banned from schools and any other places where children could access it. The following week, the Council of Europe issued a declaration calling on the Seimas to eliminate all discriminatory references to homosexual and bisexual relationships from the legislation (Council of Europe Parliamentary Assembly, 2009), and although the Lithuanian president vetoed the law shortly thereafter, the Seimas overrode it and the law will likely enter into force in March, 2010.

Just a month previous, the Chairman of the Council of Europe's Committee of Ministers, Samuel Žbogar, Minister for Foreign Affairs 
in Slovenia, expressed concern about the negative action taken against the organizers of the Moscow Pride Parade. "People belonging to sexual minorities," he observed, "enjoy the same right to freedom of expression and to freedom of assembly as any other individual within the jurisdiction of a member state of the Council of Europe" (Council of Europe Press Division, 2009).

As this issue of the journal goes to press, the UNDP, the lead agency on HIV and MSM issues within the UNAIDS framework, is preparing a policy brief with WHO Europe on HIV and MSM in Eastern Europe. As the brief will show, much of what needs to be done is already well known. Sex between men has to be truly decriminalized in every country of the region, and political leaders must show the way in destigmatizing homosexuality. For their part, healthcare providers need to ensure that MSM have access to appropriate sexual health services. It is their professional duty to provide such care regardless of personal opinions. And finally, the international community needs to maintain its commitment to universal access by ensuring prevention, treatment, and care for MSM in a culturally sensitive manner - a commitment that local and national organizations, particularly NGOs, can help them honor.

\section{REFERENCES}

Bozicevic, I., Voncina. L., Zigrovic, L., Munz, M., \& Lazarus, J. V. (2009). Know your epidemic: HIV epidemics among men who have sex with men in 27 countries of eastern Europe. Sexually Transmitted Infections, 85, 336-342.

Council of Europe Parliamentary Assembly. (2009). 23 June 2009: Lithuanian Law on the protection of minors restricts publication of information on homosexual and bisexual relations (Written Declaration No. 28, Doc.11969). Strasbourg, France: Council of Europe. Retrieved July 2, 2009 from http://assembly.coe.int/Main.asp?link=/Documents/ WorkingDocs/Doc09/EDOC11969.htm.

Council of Europe Press Division. (2009). Concern over Moscow Pride Parade (Press release 398). Strasbourg, France: Council of EuropeRetreived July 13, 2009 from https://wcd.coe.int/ViewDoc.jsp?id=1445933.

UNAIDS. (2009a). 2008 progress reports submitted by countries. Retreived July 16, 2009 from http://www.unaids.org/en/KnowledgeCentre/HIVData/ CountryProgress/2007CountryProgressAllCountries.asp.

UNAIDS. (2009b). UNAIDS action framework: universal access for men who have sex with men and transgender people. Geneva: Author. Retrieved July 13, 2009 from http://www . unaidsrstesa . org/files / ActionFramework MSM_en.pdf.

World Health Organization Regional Office for Europe. (2008). HIV and other STIs among MSM in the European Region: Report on a consultation. Copenhagen: Author. Retreived July 2, 2009 from http:// www.euro.who.int/document/SHA/bled_report.pdf. 